\title{
Plantar flexion and flexion synergy in brain death
}

回承

An 18-year-old man with anaplastic oligoastrocytoma was pronounced brain dead based on absent confounding factors, absent brainstem reflexes, apnea with $\mathrm{CO}_{2}$ challenge, and isoelectric EEG. Plantar flexion, triple flexion response, and undulation toes were noted bilaterally and remained for 32 hours during organ procurement.

Although in our experience toes and legs in patients declared brain dead are mostly immobile after noxious stimulation or plantar stimulation, one study noted retained flexion reflexes in more than $50 \%$ of patients. ${ }^{1}$ Corticoreticular disconnection may leave disorganized fragments of unisegmental (undulating toes and plantar flexion ${ }^{2}$ ) or polysegmental (triple flexion response) spinal reflexes.

Alexander Y. Zubkov, MD, PhD, and Eelco F.M. Wijdicks, MD, PhD, Rochester, MN

Disclosure: The authors report no conflicts of interest.

Address correspondence and reprint requests to Dr. Eelco F.M. Wijdicks, 200 First Street SW, Rochester, MN 55901; wijde@mayo.edu.

Supplemental data at www.neurology.org
1. de Freitas GR, Andre C. Absence of the Babinski sign in brain death: a prospective study of 144 cases. J Neurol 2005;252:106-107.

2. McNair NL, Meador KJ. The undulating toe flexion sign in brain death. Mov Disord 1992;7:345-347. 


\title{
Neurology
}

\author{
Plantar flexion and flexion synergy in brain death \\ Alexander Y. Zubkov and Eelco F.M. Wijdicks \\ Neurology 2008;70; 74 \\ DOI 10.1212/01.wnl.0000311393.07219.a2
}

This information is current as of May 5, 2008

\section{Updated Information \&} Services

Supplementary Material

\section{References}

Citations

Subspecialty Collections

Permissions \& Licensing

Reprints including high resolution figures, can be found at: http://n.neurology.org/content/70/19/e74.full

Supplementary material can be found at: http://n.neurology.org/content/suppl/2008/05/04/70.19.e74.DC1

This article cites 2 articles, 0 of which you can access for free at: http://n.neurology.org/content/70/19/e74.full\#ref-list-1

This article has been cited by 1 HighWire-hosted articles: http://n.neurology.org/content/70/19/e74.full\#\#otherarticles

This article, along with others on similar topics, appears in the following collection(s):

Brain death

http://n.neurology.org/cgi/collection/brain_death

Information about reproducing this article in parts (figures,tables) or in its entirety can be found online at:

http://www.neurology.org/about/about_the_journal\#permissions

Information about ordering reprints can be found online: http://n.neurology.org/subscribers/advertise

Neurology ${ }^{\circledR}$ is the official journal of the American Academy of Neurology. Published continuously since 1951, it is now a weekly with 48 issues per year. Copyright . All rights reserved. Print ISSN: 0028-3878. Online ISSN: 1526-632X.

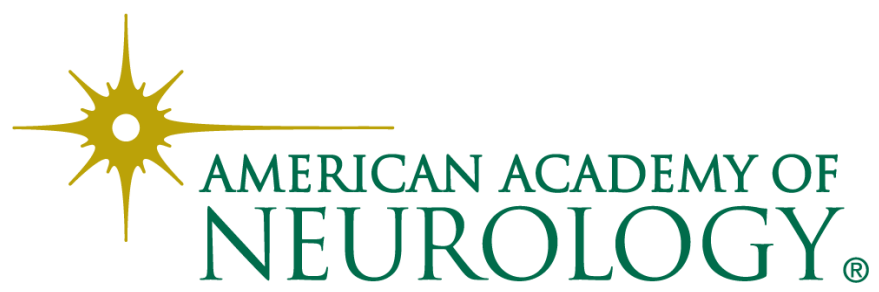

